УДК 330.88

\title{
ЦИРКУЛЯРНА ЕКОНОМІКА В СИСТЕМІ СТАЛОГО РОЗВИТКУ АГРАРНОГО СЕКТОРА В УМОВАХ ЄВРОІНТЕГРАЦІї
}

\section{CIRCULAR ECONOMY IN THE SYSTEM OF SUSTAINABLE DEVELOPMENT OF AGRARIAN SECTOR IN THE CONDITIONS OF EUROPEAN INTEGRATION}

\author{
Кучер Анатолій Васильович \\ доктор економічних наук, старший дослідник, \\ Харківський національний університет імені В.Н. Каразіна \\ ORCID: https://orcid.org/0000-0001-5219-3404 \\ Кучер Леся Юріївна \\ доктор економічних наук, старший науковий співробітник, \\ Державний біотехнологічний університет \\ ORCID: https://orcid.org/0000-0001-7112-8763
}

Пащенко Юлія Валентинівна

кандидат економічних наук, доцент,

Державний біотехнологічний університет

ORCID: https://orcid.org/0000-0002-4788-0581

\author{
Kucher Anatolii \\ V.N. Karazin Kharkiv National University
}

Kucher Lesia, Pashchenko Yuliia

State Biotechnology University

\footnotetext{
Статтю присвячено теоретичному аналізу тенденцій, сучасного стану публікаційної активності та пріоритетних напрямів досліджень циркулярної економіки у світі в контексті сталого розвитку аграрного сектора в Україні. У світі ідентифріковано тенденцію до істотного зростання інтенсивності досліджень із циркулярної економіки, особливо починаючи з 2016 р. Світовими лідерами за кількістю публікацій із циркулярної економіки є Італія, Китай, Англія, Іспанія та Німеччина. В Україні ці питання перебувають на початковій стадії, при цьому протягом останніх п'яти років виявлено тенденцію до зростання публікаційної активності в 7,7 раза. Циркулярна економіка є міждисциплінарним об'єктом досліджень, при цьому більшість праць опубліковано за профрілем наук про довкілля, інженерії, енергетики, бізнесу, менеджменту, обліку й соціальних наук.

Ключові слова: циркулярна економіка, сталий розвиток, аграрний сектор, бібліометричний аналіз, Європейський зелений курс.

Статья посвящена теоретическому анализу тенденций, современного состояния публикационной активности и приоритетных направлений исследований циркулярной экономики в мире в контексте устойчивого развития аграрного сектора в Украине. В мире идентифицирована тенденция к существенному росту интенсивности исследований по циркулярной экономике, особенно начиная с 2016 г. Мировыми лидерами по количеству публикаций по циркулярной экономике являются Италия, Китай, Англия, Испания и Германия. В Украине эти вопросы находятся на начальной стадии, при этом за последние пять лет выявлена тенденция к росту публикационной активности в 7,7 раза. Циркулярная экономика является междисциплинарным объектом исследований, при этом большинство работ опубликовано по профрилю наук об окружающей среде, инженерии, энергетики, бизнеса, менеджмента, учета и социальных наук.

Ключевые слова: циркулярная экономика, устойчивое развитие, аграрный сектор, библиометрический анализ, Европейский зеленый курс.
} 
The article is devoted to the theoretical analysis of trends, the current state of publishing activity and priority areas of research in the circular economy in the world in the context of sustainable development of the agricultural sector in Ukraine. The analysis of publishing activity on the circular economy according to the Scopus database allowed us to draw the following conclusions: 1) In the world, a tendency towards a significant increase in the intensity of research on the circular economy has been identified, especially since 2016; 2) The world leaders in terms of the number of publications on the circular economy are Italy $(14,2 \%)$, China $(13,2 \%)$, United Kingdom (10,6\%), Spain $(9,4 \%)$ and Germany $(6,3 \%) ; 3)$ In Ukraine, these issues are at an early stage, while over the past five years, a tendency towards an increase in publication activity has been revealed by 7.7 times; 4) Circular economics is an interdisciplinary research object, with most of the work published in the field of environmental sciences (22,7\%), engineering (14,6\%), energy (12,5\%), business, management, accounting (7,8\%) and social sciences (7,7\%); 4$)$ According to the number of publications on the circular economy, the most influential organization in the world is Delft University of Technology, the most influential scientist - Chinese Professor Y. Geng; 5) In the world insufficient attention is paid to the circular agricultural economy; most of the work of Ukrainian scholars focuses on the relationship between the circular economy and waste management and the European integration, none of which relate to the agricultural sector. Taking into account the assessment of the current state of scientific support of the circular economy and the need to implement the European Green Deal, a promising area of research is the substantiation of a strategy for the development of a circular digital agricultural economy, which will contribute to the sustainable development of Ukraine's agricultural sector in the context of European integration.

Keywords: circular economy, sustainable development, agricultural sector, bibliometric analysis, European Green Deal.

Постановка проблеми. Як відомо, Європейський Зелений Курс (European Green Deal - EGD) € дорожньою картою заходів, що «перетворять Євросоюз на ефрективну, стійку та конкурентоспроможну економіку, визначать засоби перетворення Європи на перший у світі кліматично нейтральний континент до 2050 р., стимулюючи розвиток економіки, покращення здоров'я та якості життя людей, а також трансформують кліматичні й екологічні виклики на можливості у всіх ссрерах та політиках $€ C$, гарантуючи справедливий та інклюзивний характер зеленого переходу». Ключовими напрямами EGD є чиста енергія, кліматична дія, будівництво та реновація, стійка промисловість, стійка мобільність, зменшення забруднення довкілля, біорізноманіття, стійка аграрна політика (стратегія «Від лану до столу»). EGD є глобальним процесом, що включає міжнародну торгівлю та забезпечення міжнародних ланцюгів поставок «зелених» товарів. Основні положення щодо досягнення еко-цілей EGD в аграрному секторі закріплено в рамках рефрорми Спільної аграрної політики ЄС (САР) та стратегій $€ C$ про біорозмаїття і «Від лану до столу» [1]. У зв'язку із цим $є$ потреба в активізації досліджень щодо розвитку циркулярної аграрної економіки.

Аналіз останніх досліджень і публікацій. Британські екологічні економісти Д. Пірс і Р. Тернер одні з перших у світі запропонували модель циркулярної економіки, яка нині $\epsilon$ альтернативою лінійній економіці. На теперішньому етапі в зарубіжних публікаціях питання розвитку циркулярної економіки активно досліджують, про що переконливо буде пока- зано далі в статті. Серед досліджень українських учених, присвячених розвитку глобальної циркулярної економіки, слід виділити монографрію І. Зварич [3], у якій розкрито теоретико-методологічні основи побудови циркулярного суспільства та циркулярної економіки за умов глобалізованого управління відходами. Парадигма циркулярної економіки, зазначає І. Зварич, це «виробнича модель, спрямована на підтримку сталого економічного розвитку без завдання шкоди навколишньому середовищу» [3, с. 289]. Українські економісти-аграрники розвинули теоретичні засади циркулярної економіки, мета якої забезпечити сталий розвиток шляхом оптимізації використання ресурсного потенціалу й інноваційних бізнес-моделей за умови системної державної підтримки [4]; визначили переваги циркулярної економіки та підходи до державної підтримки їі розвитку через призму дослідження ефективності політики Китаю та країн ЄС щодо її імплементації [5]; здійснили огляд наявних систем показників циркулярної економіки в аграрному секторі, які розподілено за стратегіями звуження, закриття та відновлення ресурсних циклів у контексті технічного, екологічного, економічного та соціального вимірів сталості [6].

Виділення невирішених раніше частин загальної проблеми. Не зважаючи на істотну увагу з боку зарубіжних науковців і практиків до зазначеної тематики, нині в Україні питання розвитку циркулярної економіки, у тому числі в аграрному секторі, перебувають на початковому етапі, зокрема в частині обґрунтування теоретичних, методологічних і прикладних засад циркулярної цифррової аграрної економіки. 
Формулювання цілей статті. Метою статті $\epsilon$ висвітлення результатів теоретичного аналізу тенденцій, сучасного стану публікаційної активності та пріоритетних напрямів досліджень циркулярної економіки у світі на основі бази Scopus у контексті сталого розвитку аграрного сектора в Україні.

Виклад основного матеріалу дослідження. Реалізація EGD безпосередньо пов'язана з імплементацією принципів циркулярної економіки, зокрема, в аграрному секторі, що потребує переорієнтації агробізнесу в напрямі екологізації виробництва й розвитку розумного землеробства. Зокрема, передбачено зниження використання пестицидів (на 25\% - до 2030 р.), мінеральних добрив та антибіотиків (на $25 \%$ - до 2030 р.) у сільському господарстві, а також введення заборони на імпорт харчової продукції з ринків, де держави не дотримуються законодавства $€ С$ 3 охорони довкілля [1]. У січні 2021 р. Міністр розвитку економіки, торгівлі та сільського господарства України І. Петрашко зазначив, що мета «досягти кліматичної нейтральності у 2050 р. є цілком реальною для України. Якщо розібрати стратегію EGD, а також програмні документи ЄС щодо циркулярної економіки та сільського господарства (Farm to Fork), то ми побачимо, що в Україні багато елементів цих політик вже впроваджується» [2]. Міністерство має намір оформити свою політику щодо розвитку циркулярної економіки в самостійну стратегію й продовжувати діалог із бізнесом щодо ії реалізації. Крім того, «ефрективність сільського господарства України є важливою як для досягнення цілей політики ЄC Farm to Fork, так і для забезпечення продовольчої безпеки ЄС та ширшого регіону Європи та Середземномор'я» [2].

Аналіз публікаційної активності за базою Scopus показав істотне зростання інтенсивності досліджень із циркулярної економіки у світі, особливо починаючи з 2016 р. (рис. 1). Результати дослідження показали, що загалом за 2001-2021 рр. у Scopus проіндексовано 12404 опублікованих документів, що містили фрразу «сіrcular economy» у назві, анотації та/або ключових словах (TITLE-ABS-KEY). Так, перша публікація з'явилася у 2001 р.; до 2015 р. їх щорічна кількість не перевищувала 151 од.; максимум публікаційної активності характерний для 2021 р. (4016 документів станом на 10.11.2021 р.). Загалом в останні роки кількість публікацій у світі щодо циркулярної економіки збільшувалася дуже високими темпами, оскільки характер кривої вказує на експоненційний ріст публікаційної активності. Світовими лідерами за кількістю публікацій є Італія (1767 робіт або 14,2\% від загального обсягу), Китай (1641 робота або 13,2\%), Англія (1321 робота або 10,6\%), Іспанія (1172 роботи або 9,4\%) та Німеччина (787 робіт або 6,3\%) (рис. 2). Українські вчені опублікували 55 робіт, що становить 0,44\% світового потоку публікацій, відповідно в загальному рейтингу Україна посідала 38-му позицію. Хронологічний аналіз свідчить, що вчені з українською афіліацією були авторами чи співавторами у 2017 р. трьох проіндексованих документів, у 2018 р. - п'яти документів, у 2019 р. - 12, у 2020 р. - 12, у 2021 р. - 23 документів. Отже, близько $42 \%$ українських робіт стосуються останнього аналізованого року. Попри певні наукові дискусії, на рівні ЄС офріційно визнано доцільність переходу до циркулярної економіки, про що свідчить затверджений у 2020 р. «Circular Economy Action Plan For a cleaner and more competitive Europe». В Україні ці питання наразі ще перебувають на початковій стадії.

Аналіз ТОП-10 організацій світу за кількістю проіндексованих у Scopus публікацій, які містять у назві, анотації та/або ключових словах термін «n circular economy» (рис. 3) свідчить, що представники трьох університетів / наукових центрів опублікували відповідно 204, 164 та 143 роботи, решта - від 122 до 97 документів. Отже, Делфртський технологічний університет (Нідерланди) є світовим лідером у дослідженні аналізованої проблеми.

Аналіз за типом документів свідчить, що більше половини $(63,1 \%)$ робіт опубліковано у формі статей; 17,1\% - конореренційні матеріали; $11,3 \%$ - рецензії (огляди); 4,3\% - розділи книг. Результати аналізу документів за галузями знань вказують на те, що циркулярну економіку досліджують із позиції різних наук. Найбільше документів опубліковано за проорілем наук про довкілля (22,7\%), інженерії $(14,6 \%)$, енергетики (12,5\%), дещо менше - у сорері бізнесу, менеджменту й обліку (7,8\%) і соціальних наук $(7,7 \%)$. У галузі економіки, економетрики та фрінансів опубліковано 995 робіт (3,6\%), у сорері аграрних і біологічних наук - 926 документів (3,4\%). Отже, у світі циркулярну економіку досліджують переважно з позиції наук про довкілля, інженерії, енергетики, бізнесу, менеджменту, обліку й соціальних наук (сукупно 65,3\%). Загалом на економічні науки припадало 11,4\% світового обсягу публікацій. Водночас 15,3\% публікацій стосуються категорії «інші науки», що 


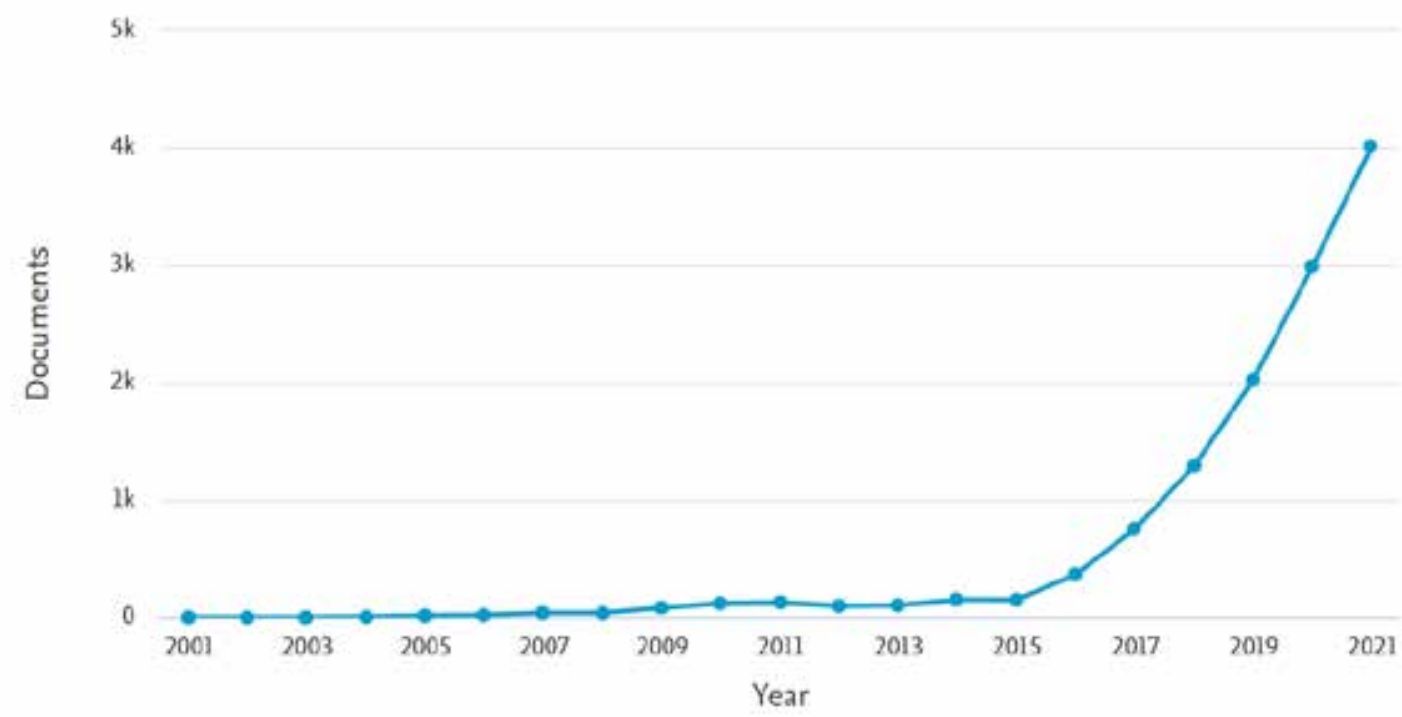

Рис. 1. Динаміка кількості проіндексованих у Scopus публікацій, які містять у назві, анотації, ключових словах термін «circular economy»

Джерело: побудовано на основі бази Scopus

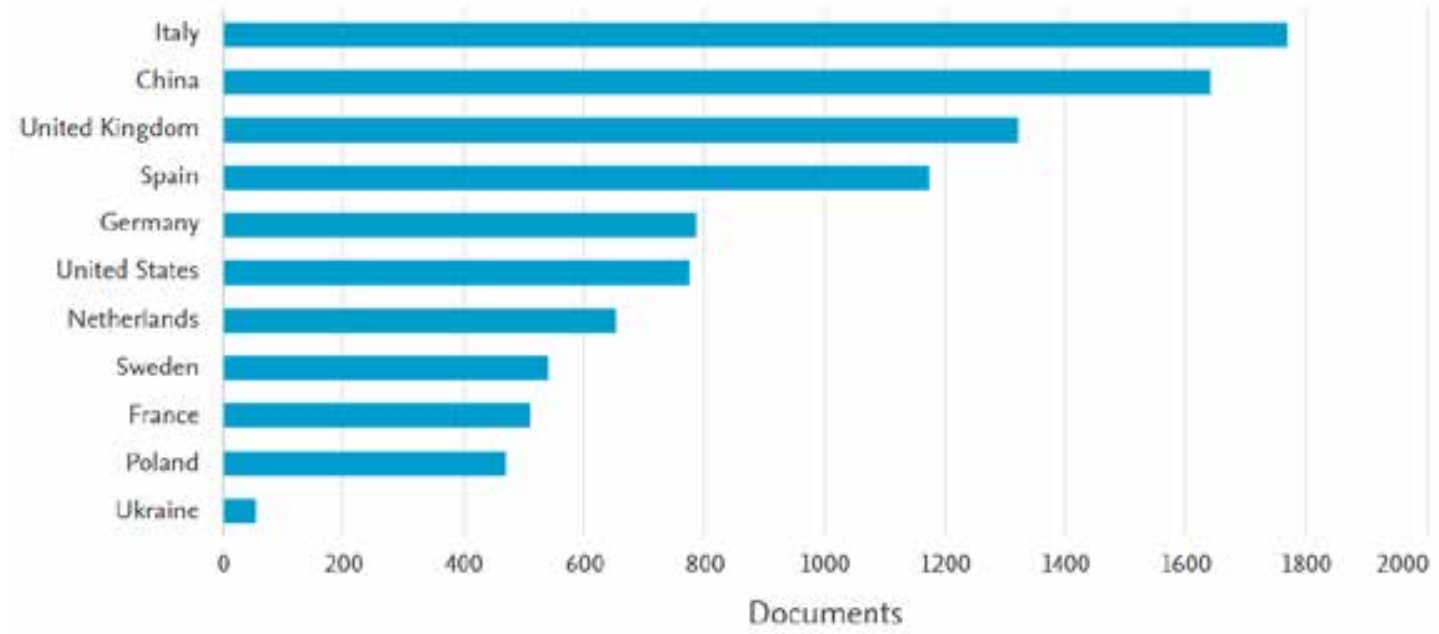

Рис. 2. Україна й ТОП-10 країн світу за кількістю проіндексованих у Scopus публікацій, які містять у назві, анотації, ключових словах термін «circular economy», 2001-2021 pp.

Джерело: побудовано на основі бази Scopus

в сукупності вказує на міждисциплінарний характер досліджень циркулярної економіки у світі й розуміння цього явище не скільки 3 економічних позицій, скільки з погляду наук про довкілля. Установлено, що до числа ТОП10 учених світу за кількістю публікацій із циркулярної економіки, проіндексованих у Scopus, належать такі: Y. Geng (30 робіт), M. Lundström (29), D.C.A. Pigosso (29), T.C. McAloone (27), S. Ramakrishna (26), P. Rosa (24), M. Smol (24), S. Terzi (23), S. Ulgiati (22), N. Bocken (22). Лідер рейтингу - китайський профресор
Y. Geng $є$ провідним ученим із циркулярної економіки та промислової екології, а також деканом Школи наук про довкілля та інженерії Шанхайського університету Цзяо Тун. Його основна наукова галузь охоплює промислову екологію, управління навколишнім середовищем, зміну клімату, облік викидів вуглецю та сталий розвиток.

Більшість проіндексованих у Scopus робіт українських учених сфрокусовані на взаємозв'язках циркулярної економіки 3 управлінням відходами та євроінтеграційним 


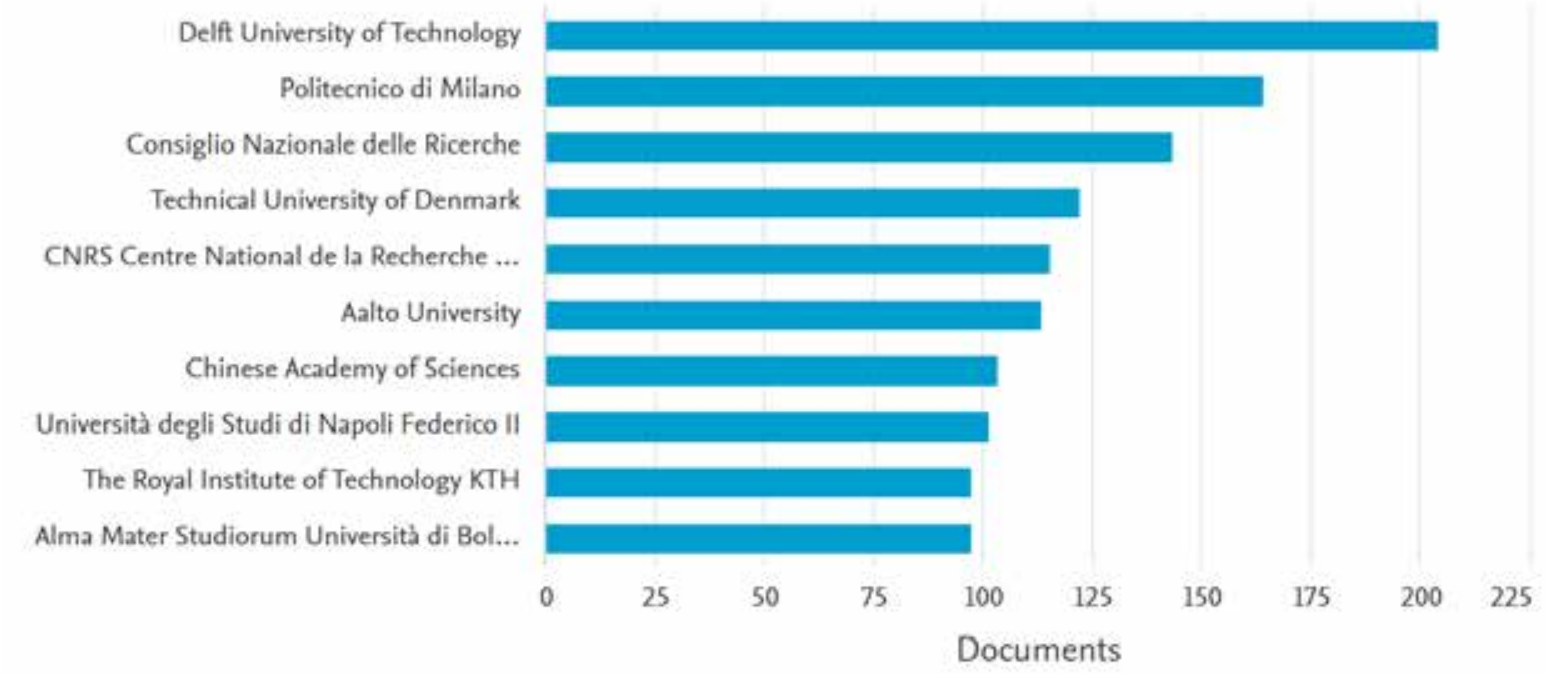

Рис. 3. ТОП-10 організацій світу за кількістю проіндексованих у Scopus публікацій, які містять у назві, анотації та/або ключових словах термін «circular economy», 2001-2021 pp.

Джерело: побудовано на основі бази Scopus

контекстом, при цьому жодна з них не стосується аграрного сектора. Недостатню увагу циркулярній аграрній економіці приділено й у світі, оскільки лише 13 робіт проіндексовано за цією тематикою. Так, учені De Pascale та ін. обґрунтували концепцію модульної системи для розвитку циркулярної економіки в сільському господарстві [7]; Хіа та ін. проаналізували перешкоди для розвитку сталої циркулярної економіки в сільському господарстві Китаю [8]; Elvanidi та ін. запропонували впровадження концепції циркулярної економіки в тепличній гідропоніці [9]; Zarbà та ін. розвинули парадигму циркулярної економіки на прикладі овочівництва в Італії [10]. Одна 3 небагатьох публікацій стосується розуміння впровадження циркулярної економіки на прикладі виробництва органічних добрив [11]. Аналіз останніх робіт щодо переробки пташиного посліду в Польщі засвідчив можливість його перетворення на продукти 3 доданою вартістю за певних технологій, при цьому основне завдання - забезпечити замикання вуглецевих, азотних і фоссрорних циклів і безпечне внесення в ґрунт (Dróżdż та ін., 2020) [12]. Разом із цим, у відомій літературі відсутня стратегія розвитку циркулярної економіки та цілісні інноваційні технології переробки аграрних відходів (зокрема, тваринництва) на продукти 3 доданою вартістю.

Висновки. У цій статті здійснено теоретичний аналіз тенденцій, сучасного стану публікаційної активності та пріоритетних напрямів досліджень циркулярної економіки у світі 3 використанням бази Scopus у контексті сталого розвитку аграрного сектора в Україні за умов євроінтеграції. Аналіз публікаційної активності з питань циркулярної економіки за даними бази Scopus дав змогу стверджувати, що: 1) у світі ідентисріковано тенденцію до істотного зростання інтенсивності досліджень із циркулярної економіки, особливо починаючи з 2016 р., при цьому рекордного значення за аналізований період вона досягла у 2021 р., що свідчить про високий рівень актуальності, науково-практичної значущості й перспективності цієї тематики; 2) серед країн світовими лідерами за кількістю публікацій із циркулярної економіки були Італія (14,2\% від загального обсягу), Китай $(13,2 \%)$, Англія $(10,6 \%)$, Іспанія $(9,4 \%)$ та Німеччина (6,3\%). В Україні ці питання перебувають на початковій стадії (0,44 \% світового потоку публікацій), при цьому в динаміці протягом 2017-2021 рр. виявлено тенденцію до зростання публікаційної активності в 7,7 раза; 3) циркулярна економіка $€$ міждисциплінарним об'єктом досліджень, при цьому більшість праць опубліковано за профрілем наук про довкілля (22,7\%), інженерії (14,6\%), енергетики (12,5\%), бізнесу, менеджменту й обліку $(7,8 \%)$ і соціальних наук $(7,7 \%) ; 4)$ установлено, що за кількістю публікацій із циркулярної економіки найбільш впливовою організацією у світі є Делсртський технологічний університет, найбільш впливовий учений - китайський профpecop Y. Geng; 5) у світі недостатню увагу приділено циркулярній аграрній економіці; більшість робіт україн- 
ських учених сорокусовані на взаємозв'язках циркулярної економіки з управлінням відходами та євроінтеграційним контекстом, при цьому жодна 3 них не стосується аграрного сектора. 3 огляду на здійснену оцінку сучасного стану наукового забезпечення цирку- лярної економіки та необхідність реалізації EGD, перспективним напрямом досліджень $€$ розроблення стратегії розвитку циркулярної цифрової аграрної економіки, що сприятиме сталому розвитку аграрного сектора України в контексті євроінтеграції.

\section{СПИСОК ВИКОРИСТАНИХ ДЖЕРЕЛ:}

1. Європейський Зелений Kypc. URL: https://ukraine-eu.mfa.gov.ua/posolstvo/galuzeve-spivrobitnictvo/klimatyevropejska-zelena-ugoda

2. І. Петрашко: Мета досягти кліматичної нейтральності у 2050 році $є$ цілком реальною для України. URL: https://www.kmu.gov.ua/news/igor-petrashko-meta-dosyagti-klimatichnoyi-nejtralnosti-u-2050-roci-ye-cilkomrealnoyu-dlya-ukrayini

3. Зварич І. Я. Глобальна циркулярна економіка: «Економіка ковбоїв» VS «Економіка космічного корабля» : моногр. Тернопіль : THEУ, 2019. 337 с.

4. Гришова І. Ю., Нестерова К. С. Концепт циркулярної економіки в контексті забезпечення сталого розвитку. Економіка АПК. 2021. № 4. С. 88-94. DOI: https://doi.org/10.32317/2221-1055.202104088

5. Нестерова К. С., Куровська І. А., Гришова Р. В. Проблеми та інструменти державної організаційно-економічної підтримки розвитку циркулярної економіки. Економіка АПК. 2021. № 5. C. 57-63. DOI: https://doi.org/ 10.32317/2221-1055.202105057

6. Страпчук С. І. Система показників оцінки ефективності стратегій циркулярної економіки в аграрному секторі. Бізнес Інфрорм. 2021. № 9. C. 108-115. DOI: https://doi.org/10.32983/2222-4459-2021-9-108-115

7. De Pascale S., De Pascale S., Rouphael Y., Cirillo V., Esposito M., Maggio A. Modular systems to foster circular economy in agriculture. Acta Horticulturae. 2021. Vol. 1320. P. 205-210. DOI: https://doi.org/10.17660/ ActaHortic.2021.1320.26.

8. Xia X., Ruan J. Analyzing barriers for developing a sustainable circular economy in agriculture in China Using Grey-DEMATEL approach. Sustainability. 2020. Vol. 12(16). 6358. DOI: https://doi.org/10.3390/su12166358

9. Elvanidi A., Reascos C.M.B., Gourzoulidou E., (...), Max J.F.J., Katsoulas N. Implementation of the circular economy concept in greenhouse hydroponics for ultimate use of water and nutrients. Horticulturae. 2020. Vol. 6(4). 83. P. 1-16. DOI: https://doi.org/10.3390/horticulturae6040083

10. Zarbà C., Chinnici G., Pecorino B., D'Amico M. Paradigm of the circular economy in agriculture: the case of vegetable seedlings for transplantation in nursery farms. International Multidisciplinary Scientific GeoConference Surveying Geology and Mining Ecology Management, SGEM. 2019. Vol. 19(4.2). P. 113-120. DOI: https://doi.org/ 10.5593/sgem2019V/4.2/S05.0163

11. Nattassha R., Handayati Y., Simatupang T.M. et al. Understanding circular economy implementation in the agri-food supply chain: the case of an Indonesian organic fertiliser producer. Agriculture \& Food Security. 2020. Vol. 9. 10. DOI: https://doi.org/10.1186/s40066-020-00264-8

12. Dróżdż D., Wystalska K., Malińska K., Grosser A., Grobelak A., Kacprzak M. Management of poultry manure in Poland - Current state and future perspectives. Journal of Environmental Management. 2020. Vol. 264. 110327. DOI: https://doi.org/10.1016/j.jenvman.2020.110327

\section{REFERENCES:}

1. Yevropeiskyi Zelenyi Kurs [European Green Course]. Retrieved from: https://ukraine-eu.mfa.gov.ua/ posolstvo/galuzeve-spivrobitnictvo/klimat-yevropejska-zelena-ugoda

2. I. Petrashko: Meta dosiahty klimatychnoi neitralnosti u 2050 rotsi ye tsilkom realnoiu dlia Ukrainy [lgor Petrashko: The goal of achieving climate neutrality in 2050 is quite real for Ukraine]. Retrieved from: https://www.kmu.gov.ua/news/ igor-petrashko-meta-dosyagti-klimatichnoyi-nejtralnosti-u-2050-roci-ye-cilkom-realnoyu-dlya-ukrayini

3. Zvarych, I. Ya. (2019) Hlobalna tsyrkuliarna ekonomika: «Ekonomika kovboiv» VS «Ekonomika kosmichnoho korablia» [Global Circular Economy: «Cowboy Economy» VS «Spacecraft Economy»]. Ternopil: TNEU. (in Ukrainian)

4. Gryshova, I. Yu. \& Nesterova, K. S. (2021) Kontsept tsyrkuliarnoi ekonomiky v konteksti zabezpechennia staloho rozvytku [The concept of a circular economy in the context of sustainable development]. Ekonomika APK, 4, 88-94. DOI: https://doi.org/10.32317/2221-1055.202104088 (in Ukrainian)

5. Nesterova, K. S., Kurovska, I. A., \& Hryshova, R. V. (2021) Problemy ta instrumenty derzhavnoi orhanizatsiino-ekonomichnoi pidtrymky rozvytku tsyrkuliarnoi ekonomiky [Problems and instruments of state organizational and 
economic support of the circular economy development]. Ekonomika APK, 5, 57-63. DOI: https://doi.org/10.32317I 2221-1055.202105057 (in Ukrainian)

6. Strapchuk, S. I. (2021) A System of Indicators for Evaluating the Efficiency of Circular Economy Strategies in the Agrarian Sector. Business Inform, 9, 108-115. DOI: https://doi.org/10.32983/2222-4459-2021-9-108-115

7. De Pascale, S., De Pascale, S., Rouphael, Y., Cirillo, V., Esposito, M., \& Maggio, A. (2021) Modular systems to foster circular economy in agriculture. Acta Horticulturae, 1320, 205-210. DOI: https://doi.org/10.17660/ActaHortic.2021.1320.26

8. Xia, X., \& Ruan, J. (2020) Analyzing barriers for developing a sustainable circular economy in agriculture in China Using Grey-DEMATEL approach. Sustainability, 12(16), 6358. DOI: https://doi.org/10.3390/su12166358

9. Elvanidi, A., Reascos, C.M.B., Gourzoulidou, E., (...), Max, J.F.J., \& Katsoulas, N. (2020) Implementation of the circular economy concept in greenhouse hydroponics for ultimate use of water and nutrients. Horticulturae, 6(4), 83, 1-16. DOI: https://doi.org/10.3390/horticulturae6040083

10. Zarbà, C., Chinnici, G., Pecorino, B., \& D'Amico, M. (2019) Paradigm of the circular economy in agriculture: the case of vegetable seedlings for transplantation in nursery farms. International Multidisciplinary Scientific GeoConference Surveying Geology and Mining Ecology Management, SGEM, 19(4.2), 113-120. DOI: https://doi.org/10.5593/sgem2019V/4.2/S05.0163

11. Nattassha, R., Handayati, Y., \& Simatupang, T.M. et al. (2020) Understanding circular economy implementation in the agri-food supply chain: the case of an Indonesian organic fertiliser producer. Agriculture \& Food Security, 9, 10. DOI: https://doi.org/10.1186/s40066-020-00264-8

12. Dróżdż, D., Wystalska, K., Malińska, K., Grosser, A., Grobelak, A., \& Kacprzak, M. (2020) Management of poultry manure in Poland - Current state and future perspectives. Journal of Environmental Management, 264, 110327. DOI: https://doi.org/10.1016/j.jenvman.2020.110327 